\title{
Modification effect of calcium-magnesia phosphate fertilizer on microstructure and mechanical properties of $\mathrm{Mg}_{2} \mathrm{Si} / \mathrm{Mg}$-4Si composite
}

\author{
Li-chang Fan, Xiao-lin Wei, Zheng Lian, *Wen-binYu, and Ren-qing Huang \\ Faculty of Materials and Energy, Southwest University, Chongqing 400715, China
}

\begin{abstract}
In order to modify in-situ synthesized $\mathrm{Mg}_{2} \mathrm{Si}$ particles in $\mathrm{Mg}_{2} \mathrm{Si} / \mathrm{Mg}-4 \mathrm{Si}$ composite, the modification effect of calcium-magnesia phosphate fertilizer on primary $\mathrm{Mg}_{2} \mathrm{Si}$ phase in $\mathrm{Mg}_{2} \mathrm{Si} / \mathrm{Mg}-4 \mathrm{Si}$ composite was investigated by means of X-ray diffraction (XRD), optical microscopy (OM), scanning electron microscopy (SEM) and energy dispersive spectroscopy (EDS) analysis. The results indicate that the morphology of the primary $\mathrm{Mg}_{2} \mathrm{Si}$ phase apparently changes from coarse dendrites to fine dispersive polygonal particles, and the mean size is decreased from $277 \mu \mathrm{m}$ to $17 \mu \mathrm{m}$. With the addition of $4.0 \mathrm{wt}$.\% calcium-magnesia phosphate fertilizer as a modifier, the ultimate tensile strength and elongation of the $\mathrm{Mg}_{2} \mathrm{Si} / \mathrm{Mg}-4 \mathrm{Si}$ composite are increased from $78.7 \mathrm{MPa}$ and $2.1 \%$ to 105.2 $\mathrm{MPa}$ and $2.6 \%$, as compared to those of the base composite, which is probably attributed to the formation of the phosphorous compound and the cluster of $\mathrm{Ca}$ compounds that acted as the heterogeneous nucleation substrates of the primary $\mathrm{Mg}_{2} \mathrm{Si}$ particles, resulting in a refined distribution of these precipitates.
\end{abstract}

Key words: hot crack; composite; calcium-magnesia phosphate fertilizer; modification; $\mathrm{Mg}_{2} \mathrm{Si}$
CLC numbers: TG142.22
Document code: A
Article ID: 1672-6421(2016)03-199-06

$\mathrm{R}$ ecently, metal matrix composites (MMCs) have attracted extensive attention in automobile industry, in order to meet the demands of weight reduction and fuel economization ${ }^{[1-3]}$. The hypereutectic $\mathrm{Mg}-\mathrm{S}$ particulate metal matrix composites (PMMCs) have high potential as structural materials because the reinforcing particulate $\mathrm{Mg}_{2} \mathrm{Si}$ intermetallic exhibits a low density of $1.99 \times 10^{3} \mathrm{~kg} \cdot \mathrm{m}^{-3}$, a high elastic modulus of $120 \mathrm{GPa}$, a high melting temperature of $1,085^{\circ} \mathrm{C}$, a high hardness of $4.5 \times 10^{9} \mathrm{~N} \cdot \mathrm{m}^{-2}$ and a low thermal expansion coefficient of $7.5 \times 10^{-6} \mathrm{~K}^{-1[4,5]}$.

However, as in-situ $\mathrm{Mg}_{2} \mathrm{Si}$ reinforced PMMCs, hypereutectic $\mathrm{Mg}-\mathrm{Si}$ alloys do not have satisfactory mechanical properties in general, due to the exhibition of coarse dendritic primary $\mathrm{Mg}_{2} \mathrm{Si}$ particles and the brittle Chinese script shape eutectic $\mathrm{Mg}_{2} \mathrm{Si}$ phases ${ }^{[5,6]}$. It was proposed that a modification process seems to be the

\section{*Wen-bin Yu}

Male, born in 1964, Professor. His research interests mainly focus on metal matrix composites and non-ferrous metals.

E-mail:ywb2747@126.com

Received: 2016-04-04; Accepted: 2016-05-01 most hopeful route to improve the mechanical properties of in-situ composite prepared by simple casting ${ }^{[7]}$. The modification mechanisms of the $\mathrm{Mg}_{2} \mathrm{Si}$ particles by adding various elements, such as $\mathrm{B}^{[8]}, \mathrm{Ba}^{[9]}, \mathrm{Ca}^{[10,11]}, \mathrm{P}^{[12,13]}$ and $\mathrm{RE}^{[14-16]}$, have been discussed in previous studies. Generally, there are two major modification mechanisms for primary $\mathrm{Mg}_{2} \mathrm{Si}$ grains. One is the poisoning effect: the modification elements gather on the forehead of growth and restrict the crystal growth ${ }^{[17]}$. The other is heterogeneous nucleation: the modification elements or their compounds act as the heterogeneous nucleus ${ }^{[13,18]}$.

Currently, most scholars considered that the modification mechanism of $\mathrm{Ca}$ onto primary $\mathrm{Mg}_{2} \mathrm{Si}$ belong to poisoning effect ${ }^{[10,11]}$, and $\mathrm{P}$ to heterogeneous nucleation. Usually, the modifier containing $\mathrm{P}$ element was added into $\mathrm{Al}$ and $\mathrm{Mg}$ alloys via two ways: pure element or master alloy ${ }^{[12,13]}$. Meanwhile, the constituent nature of the heterogeneous nuclei of primary $\mathrm{Mg}_{2} \mathrm{Si}$ is still in dispute. $\mathrm{Kim}^{[19]}$ and Schmid, et al. ${ }^{[20]}$ reported that the nucleus of primary $\mathrm{Mg}_{2} \mathrm{Si}$ is $\mathrm{Mg}_{3}\left(\mathrm{PO}_{4}\right)_{2}$. Nevertheless, Zhao ${ }^{[13]}$ and Liu, et al ${ }^{[21]}$ via EPMA analysis showed that AlP particles act as the cores of primary $\mathrm{Mg}_{2} \mathrm{Si}$. Furthermore, Hou ${ }^{[22]}$ suggested that $\mathrm{Mg}_{3} \mathrm{P}_{2}$ phases serve as the heterogeneous nucleation substrates of primary 
$\mathrm{Mg}_{2} \mathrm{Si}$.

However, little has been reported on the addition of a modifier containing $\mathrm{P}$ element by use of phosphate, and there is no investigation on the modification of $\mathrm{Mg}_{2} \mathrm{Si}$ by the combination of $\mathrm{P}$ and $\mathrm{Ca}$. In this work, the modification effects of calciummagnesia phosphate fertilizer as a modifier in in-situ $\mathrm{Mg}_{2} \mathrm{Si} / \mathrm{Mg}$ $\mathrm{Si}$ composite is investigated and the purpose of this preliminary experimental study is to find an effective and simplified casting process route to produce a relatively fine and dispersive $\mathrm{Mg}_{2} \mathrm{Si}$ particle reinforced magnesium metal matrix composite.

\section{Experimental procedure}

Pure magnesium (> 99.8 wt.\%) and Mg-6.29wt.\%Si master alloy were used as raw materials to prepare the investigated $\mathrm{Mg}_{2} \mathrm{Si} / \mathrm{Mg}-4 \mathrm{Si}$ composites in a graphite crucible heated by an electric resistance furnace. About $700 \mathrm{~g}$ of $\mathrm{Mg}-6.29 \mathrm{wt} . \% \mathrm{Si}$ alloys ( $10 \%$ burning loss for $\mathrm{Si}$ ) preheated to $200{ }^{\circ} \mathrm{C}$ were added into $500 \mathrm{~g}$ pure $\mathrm{Mg}$ melt (20\% burning loss for $\mathrm{Mg}$ ) at $760{ }^{\circ} \mathrm{C}$ under Ar flux protection. After about $20 \mathrm{~min}$, the dewatered calcium-magnesia phosphate fertilizer was added into the melt and stirred for about 5 min to obtain the modified composites with the designed fertilizer additions of $3 \%, 4 \%, 5 \%$ and $6 \%$. After holding for $15 \mathrm{~min}$, each melt was poured into a steel mould to produce columnar bars of $\Phi 15 \mathrm{~mm} \times 100 \mathrm{~mm}$. The commercial calcium-magnesia phosphate fertilizer is produced under Chinese standard (GB 20412-2006).

All the observed specimens were cut at the same position

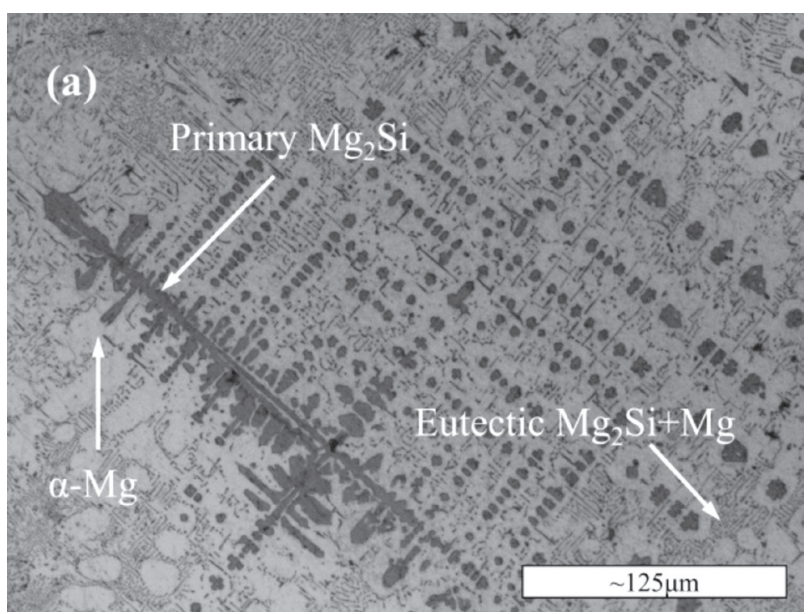

of the columnar bars, $10 \mathrm{~mm}$ from the bottom, and prepared in accordance with standard procedures as well as etched by $4 \mathrm{vol} . \%$ nital for $10 \mathrm{~s}$. The microstructures of the investigated composites were observed using optical microscope and scanning electron microscope (SEM, JSM-6610) equipped with an energy-dispersive spectrometer (EDS, Inca X-Max). The average sizes of primary $\mathrm{Mg}_{2} \mathrm{Si}$ particles were measured using image-pro plus 6.0 software and each reading was an average of 10 separate measurements at random field. The phase constituent analysis was carried out by X-ray diffraction (XRD, Shimadzu XRD-7000). The tensile tests were conducted on an electronic universal testing machine (WDW3050) at a constant crosshead speed of $1 \mathrm{~mm} \cdot \mathrm{min}^{-1}$, and the ultimate tensile strength and elongation of the $\mathrm{Mg}_{2} \mathrm{Si} / \mathrm{Mg}-4 \mathrm{Si}$ composites were determined by the mean value of 3 specimens.

\section{Results and discussion}

\subsection{Microstructure of unmodified $\mathrm{Mg}_{2} \mathrm{Si} / \mathrm{Mg}$ - 4Si composite}

Figure 1 shows the representative microstucture and XRD pattern of the unmodified $\mathrm{Mg}_{2} \mathrm{Si} / \mathrm{Mg}-4 \mathrm{Si}$ composite. The microstructure of the unmodified $\mathrm{Mg}_{2} \mathrm{Si} / \mathrm{Mg}-4 \mathrm{Si}$ composite consisted of dendritic primary $\mathrm{Mg}_{2} \mathrm{Si}$ particles, lamellar eutectics of $\mathrm{Mg}+\mathrm{Chinese}$ script type $\mathrm{Mg}_{2} \mathrm{Si}$ and $\alpha-\mathrm{Mg}$ halos, as marked in Fig. 1a. As shown in Fig. 1b, the XRD result reveals that the phase constituents of the obtained composite are $\mathrm{Mg}_{2} \mathrm{Si}$ and $\mathrm{Mg}$ phases, which completely fit the predictions ${ }^{[23]}$.

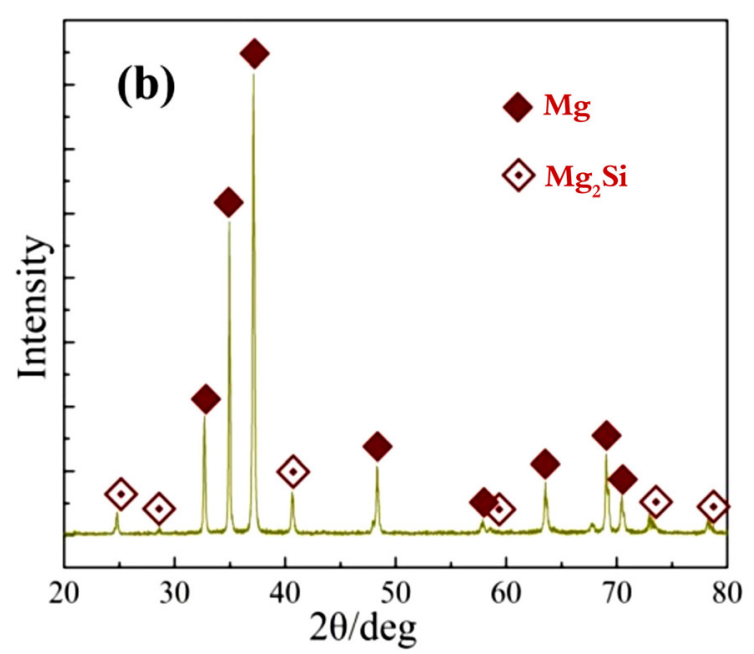

Fig. 1: (a) OM microstructure and (b) XRD pattern of unmodified $\mathrm{Mg}_{2} \mathrm{Si} / \mathrm{Mg}-4 \mathrm{Si}$ composite

\subsection{Microstructures of $\mathrm{Mg}_{2} \mathrm{Si} / \mathrm{Mg}-4 \mathrm{Si}$ composites modified with calcium- magnesia phosphate fertilizer}

Figures 2 and 3 show the XRD patterns and OM micrographs of the tested composites. According to the XRD patterns, as shown in Fig. 2, the phase components of all modified composites are still $\alpha-\mathrm{Mg}$ and $\mathrm{Mg}_{2} \mathrm{Si}$ phases. No new phase was detected. As shown in Fig. 3, the morphology of primary $\mathrm{Mg}_{2} \mathrm{Si}$ changed from coarse dendrite (Fig. 1a) to fine dispersive polygon particles when calcium-magnesia phosphate fertilizer modifier was added into the composite. The average grain sizes of the primary $\mathrm{Mg}_{2} \mathrm{Si}$ and $\alpha-\mathrm{Mg}$ halos were decreased initially and then slowly increased with the increase of modifier content of the calcium-magnesia phosphate fertilizer, as shown in Fig. 4. It is obvious from Fig. 4 and Fig. 3(b) that the finest size of primary $\mathrm{Mg}_{2} \mathrm{Si}$ particles is $17 \mu \mathrm{m}$ which was obtained in the condition of 


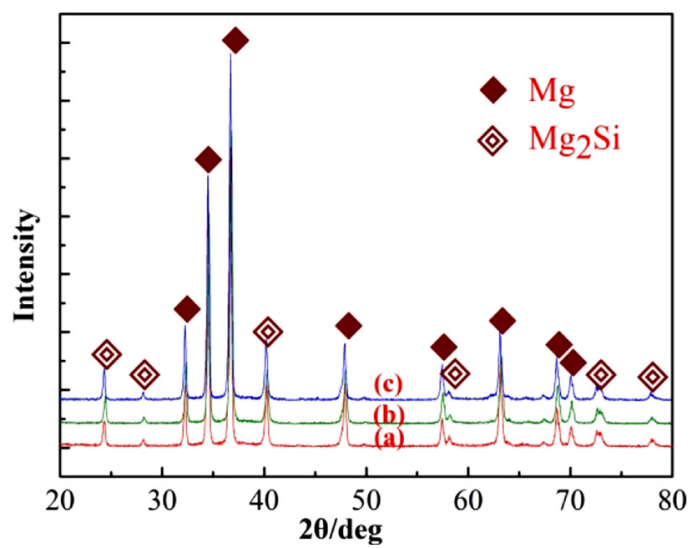

Fig. 2: XRD patterns of modified composites with (a) 4.0 wt.\%, (b) 5.0 wt.\% and (c) $6.0 w t . \%$ calcium-magnesia phosphate fertilizer
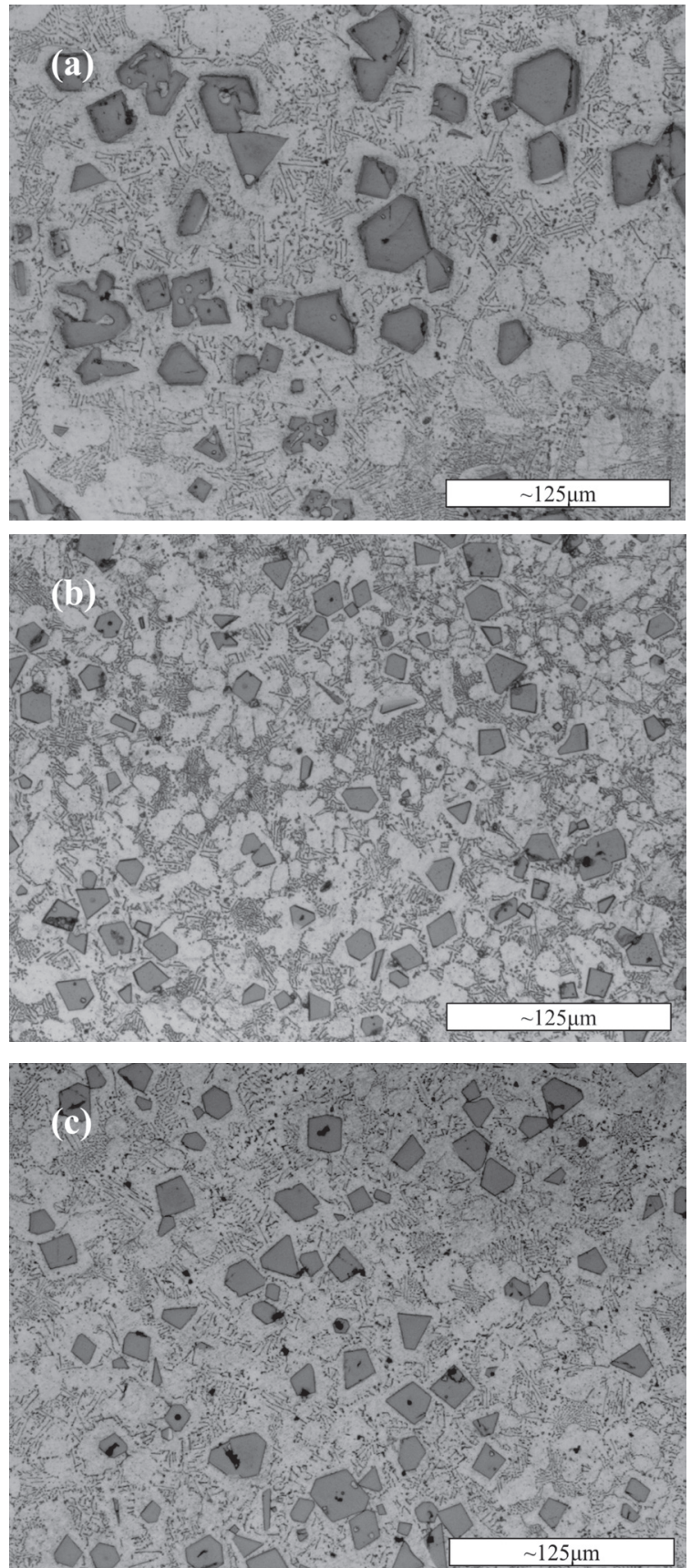

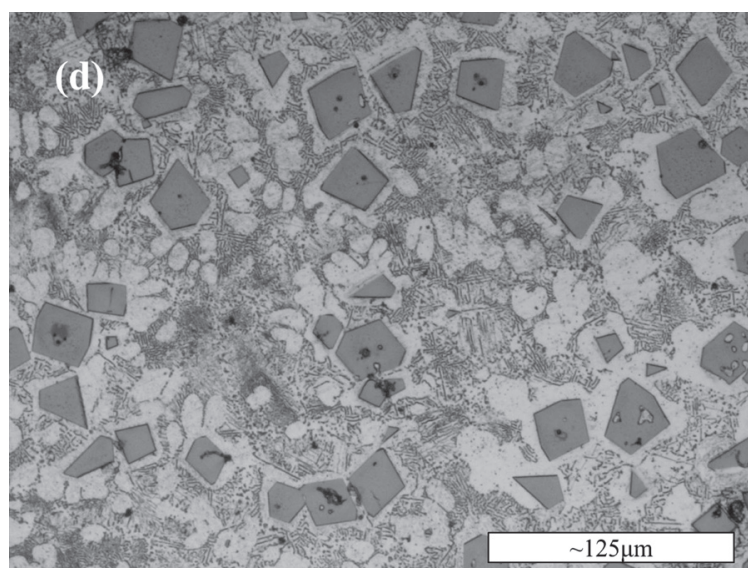

Fig. 3: OM micrographs of modified composites with (a) $3.0 \mathrm{wt} . \%$, (b) $4.0 \mathrm{wt} . \%$, (c) $5.0 \mathrm{wt} . \%$ and (d) $6.0 \mathrm{wt} . \%$ calcium-magnesia phosphate fertilizer

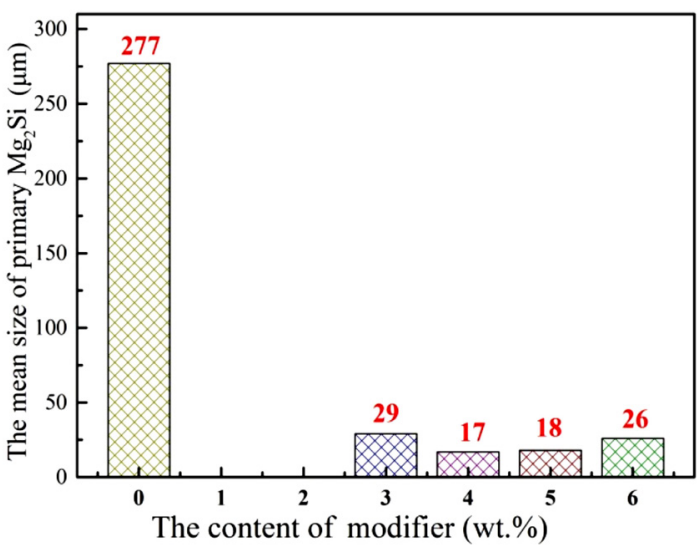

Fig. 4: Average size of primary $\mathrm{Mg}_{2} \mathrm{Si}$ particles in all investigated composites

$4.0 \mathrm{wt} . \%$ calcium-magnesia phosphate fertilizer addition. This is much smaller than that of $277 \mu \mathrm{m}$ in the unmodified composite, as shown in Fig. 4 and Fig. 1.

In the highly magnified SEM images of the composite modified with $4.0 \mathrm{wt} . \%$ calcium-magnesia phosphate fertilizer as shown in Fig. 5(a) and 5(d), it is clear that there are two tiny cores marked by crosses inside primary $\mathrm{Mg}_{2} \mathrm{Si}$ particles which may act as a heterogeneous crystallization nucleus for the primary $\mathrm{Mg}_{2} \mathrm{Si}$. In order to verify their compositions and infer the modification mechanism, further EDS analyses were carried out, as shown in Fig. 5(b), 5(c) and 5(e). The results of the EDS analyses on point $\mathrm{A}$ indicate that the core is mainly consisted of $\mathrm{Mg}, \mathrm{Si}, \mathrm{P}$ and $\mathrm{O}$ elements, and point $\mathrm{B}$ is mainly consisted of $\mathrm{Mg}, \mathrm{Si}, \mathrm{Ca}, \mathrm{P}, \mathrm{O}$ and $\mathrm{F}$ elements, as shown in Fig. 5(b) and 5(e). The EDS line scans through point A reveal that the content of $\mathrm{O}$ element at the core was changeless. Even so, the exact chemical constituents were unable to be quantified with this technique. Furthermore, there was no Al element in the melt. Hence, AlP can be excluded. Considering the information from previous studies ${ }^{[12,13,19-21]}$ and EDS detections, it is possible that the core of primary $\mathrm{Mg}_{2} \mathrm{Si}$ is phosphorous compound.

In the present study, the size and morphology of primary $\mathrm{Mg}_{2} \mathrm{Si}$ phase in the $\mathrm{Mg}_{2} \mathrm{Si} / \mathrm{Mg}-4 \mathrm{Si}$ composite are controlled by the capability of the substrate for heterogeneous nucleation 

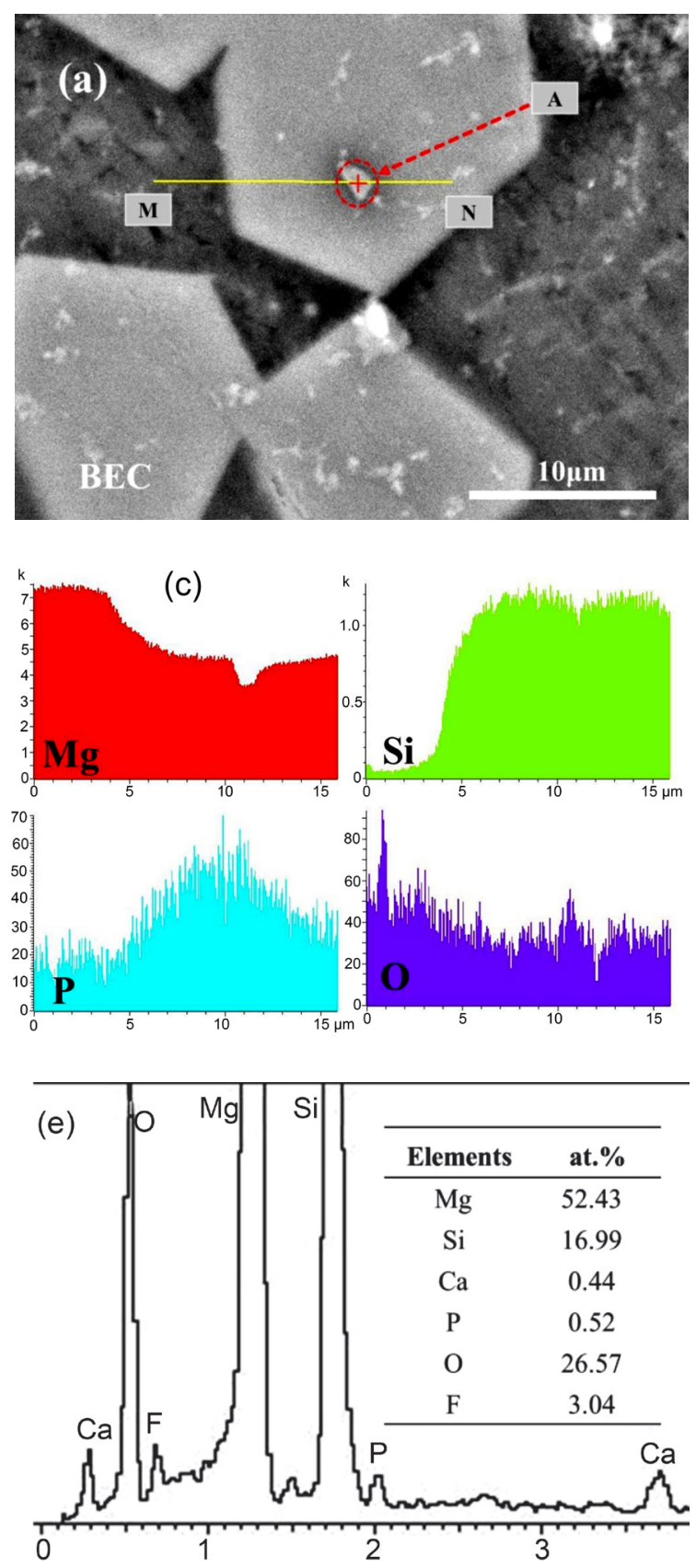

after being modified by calcium-magnesia phosphate fertilizer. The stronger the capability of the substrate for heterogeneous nucleation, the lower the undercooling degree is needed for nucleation, the more beneficial to increase the nucleation rate. The ability of heterogeneous nucleation depends on the interfacial energy between the nucleated substrate and crystalline phase ${ }^{[24]}$.

Previous investigation results show that $\mathrm{Ca}$ atoms on the growth front of the primary $\mathrm{Mg}_{2} \mathrm{Si}$ caused a poisoning effect ${ }^{[10,11]}$. Since the atomic radius of $\mathrm{Ca}\left(2.23 \times 10^{-10} \mathrm{~m}\right)$ is much larger than that of $\mathrm{Mg}\left(1.72 \times 10^{-10} \mathrm{~m}\right)$ or $\mathrm{Si}\left(1.46 \times 10^{-10} \mathrm{~m}\right)$, the surface energy of $\mathrm{Mg}_{2} \mathrm{Si}$ crystals is reduced when the $\mathrm{Ca}$ atoms in the melt adsorb onto the growing planes of $\mathrm{Mg}_{2} \mathrm{Si}$ crystals, causing the lattice distortion change of the growing habit planes and the suppression of $\mathrm{Mg}_{2} \mathrm{Si}$ growth ${ }^{[10,11]}$. Furthermore, M. E. Moussa's ${ }^{[11]}$ study shows that the $\mathrm{Ca}$ addition cannot reduce the critical nucleus
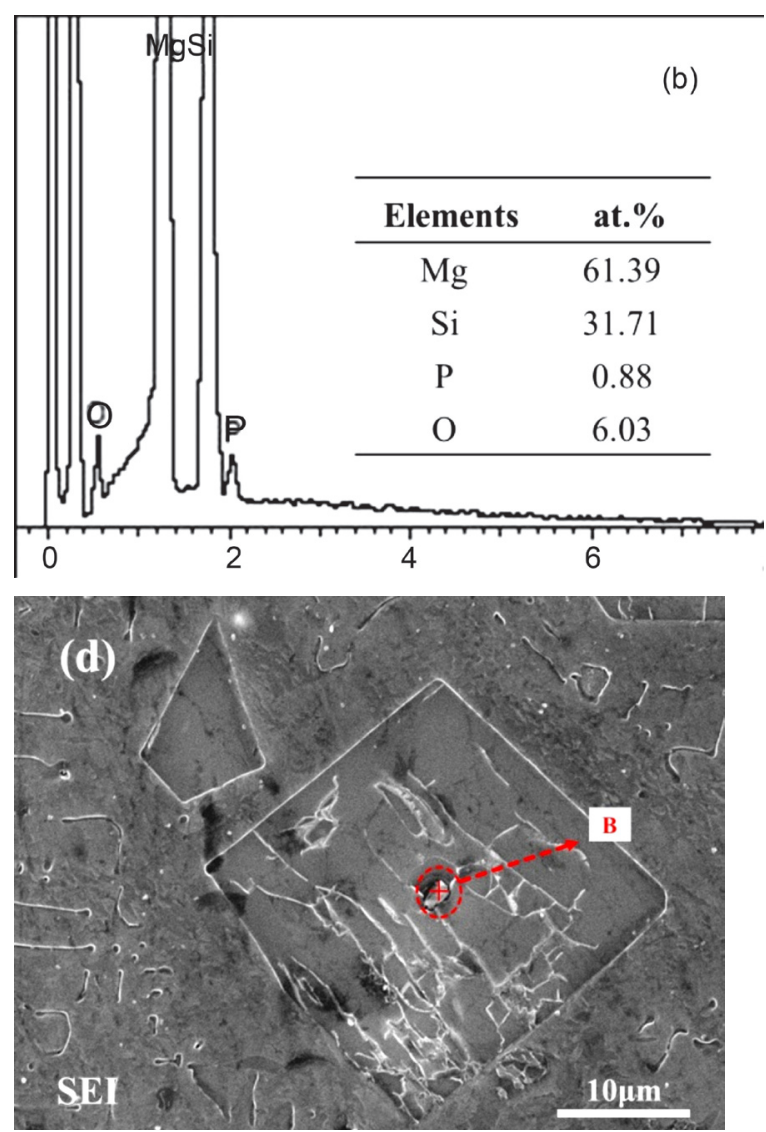

Fig. 5: (a) and (d) SEM image of the composite modified by $4.0 \mathrm{wt}$ \% calcium-magnesia phosphate fertilizer, (b) EDS results of point A, (c) EDS line scans of M-N and (e) EDS results of point $B$

radius and increase the number of potential nucleus of $\mathrm{Mg}_{2} \mathrm{Si}$. Currently, the compounds containing $\mathrm{Ca}$ elements act as the core in primary $\mathrm{Mg}_{2} \mathrm{Si}$ [in Fig. 5(d) and 5(e)]. However, the exact chemical constituent and modification mechanism of this phenomenon requires further investigation. One possibility is that, the cluster of $\mathrm{Ca}$ compounds in the melt act as an inoculant for the nucleation process. Thus, it would increase the nucleation rate of the primary $\mathrm{Mg}_{2} \mathrm{Si}$ particles. As a result, numerous primary $\mathrm{Mg}_{2} \mathrm{Si}$ nuclei cannot grow and develop to dendrite during solidification.

\subsection{Mechanical properties}

The mechanical properties of the investigated composites are determined by tensile test and the results are listed in Table 1. It can be seen that the ultimate tensile strength and elongation of the composites modified by the calcium-magnesia phosphate 
Table 1: Mechanical properties of investigated composites

\begin{tabular}{|cccccc}
\multicolumn{5}{c}{ Composite with different contents of modifier (wt.\%) } \\
& 0 & 3 & 4 & 5 & 6 \\
\hline UTS (MPa) & 78.7 & 91.2 & 105.2 & 101.4 & 95.0 \\
EL (\%) & 2.1 & 2.3 & 2.6 & 2.5 & 2.4
\end{tabular}

fertilizer are much superior to that of the unmodified $\mathrm{Mg}_{2} \mathrm{Si} / \mathrm{Mg}$ 4Si composite. With the addition of 4.0wt.\% calcium-magnesia phosphate fertilizer, the ultimate tensile strength and elongation of the $\mathrm{Mg}_{2} \mathrm{Si} / \mathrm{Mg}-4 \mathrm{Si}$ composite is increased from $78.7 \mathrm{MPa}$ and $2.1 \%$ to $105.2 \mathrm{MPa}$ and $2.6 \%$, respectively. Obviously, the improvement of mechanical properties can be mainly attributed to the change of morphology and the refinement of primary $\mathrm{Mg}_{2}$ Si particles, since micro-cracks can easily nucleate along the boundary between the $\mathrm{Mg}_{2} \mathrm{Si}$ phases and the $\mathrm{Mg}$-matrix under a lower stress ${ }^{[25,26]}$.

\subsection{Fracture characteristics}

Fracture surfaces of the unmodified and modified with 4.0wt.\% modifier $\mathrm{Mg}_{2} \mathrm{Si} / \mathrm{Mg}-4 \mathrm{Si}$ composites are shown in Fig. 6 . Basically, damage in particulate metal matrix composite (PMMCs) generally occurs at two types, particle decohesion and particle fracture ${ }^{[3]}$. When stress is applied, the matrix deforms plastically, gradually transferring stress to the particles. The behavior of the particles depends on the relative strength of the matrix/particle interface. When the matrix/particle interface is strong enough, the load is transferred to particles, with particle fracture normally occurring when the critical stress is reached. However, if the matrix/particle interface bonding is weakened, the load will not reach the critical stress, and particle decohesion arise.

When load is applied on the unmodified c o m posite, the microcrack is easily initiated from the coarse dendritic primary $\mathrm{Mg}_{2} \mathrm{Si}$ particles by debonding $\mathrm{Mg}_{2} \mathrm{Si}$ particles from matrix or self-cracking, which results in particle decohesion or particle fracture. Figure 6(a) demonstrates the coarse dendritic primary $\mathrm{Mg}_{2} \mathrm{Si}$ particles detached from matrix and both detached and cracked particles are present simultaneously in Fig. 6(b), a s previously expected.

Fig. 6: Typical micrographs of fracture surfaces in different sample: (a) and (b) unmodified, (c) and (f) with $4.0 \mathrm{wt} . \%$ modifier, (d) and (e) higher magnification of (c) 
Another effective factor on the fracture behavior is particle size. Previous results ${ }^{[3,27]}$ indicate an increase in strength and ductility by decreasing particle size. Figure 6(c), 6(d) and 6(e), clearly depicts the particle decohesion and particle fracture marked by red arrows in the $\mathrm{Mg}_{2} \mathrm{Si} / \mathrm{Mg}-4 \mathrm{Si}$ composite modified with $4.0 \mathrm{wt} . \%$ modifier. As contrast to the base composite [Fig. 6(a) and 6(b)] the cleavage characteristic becomes smaller. Furthermore, Fig. 6(f) shows the crack growth trajectory that impeded by an octahedral primary $\mathrm{Mg}_{2} \mathrm{Si}$ particles. This confirmed the functions of the $\mathrm{Mg}_{2} \mathrm{Si}$ particles in PMMCs and the effect of size, morphology and distribution of the $\mathrm{Mg}_{2} \mathrm{Si}$ particles on mechanical properties.

\section{Conclusions}

(1) The primary $\mathrm{Mg}_{2} \mathrm{Si}$ particles in the $\mathrm{Mg}_{2} \mathrm{Si} / \mathrm{Mg}-4 \mathrm{Si}$ composite can be significantly modified by the addition of calcium-magnesia phosphate fertilizer with $3 \mathrm{wt} . \%$ to $6 \mathrm{wt} . \%$. The morphology of the primary $\mathrm{Mg}_{2} \mathrm{Si}$ particles is changed from coarse dendrite to fine dispersive polygon, and the mean size is significantly decreased from $277 \mu \mathrm{m}$ to $17 \mu \mathrm{m}$.

(2) The refinement mechanism may be attributed to the appearance of phosphorous compound and the cluster of $\mathrm{Ca}$ compounds during solidification which acts as heterogeneous nucleation cores for the primary $\mathrm{Mg}_{2} \mathrm{Si}$ particles and results in the modification of primary $\mathrm{Mg}_{2} \mathrm{Si}$ particles.

(3) With 4.0wt.\% calcium-magnesia phosphate fertilizer modifier introduced, ultimate tensile strength and elongation of the $\mathrm{Mg}_{2} \mathrm{Si} / \mathrm{Mg}-4 \mathrm{Si}$ composite is increased from $78.7 \mathrm{MPa}$ and $2.1 \%$ to $105.2 \mathrm{MPa}$ and $2.6 \%$, as compared to that of the base composite.

\section{References}

[1] Jiang Q C, Wang $\mathrm{H}$ Y, Wang $\mathrm{Y}$, et al. Modification of $\mathrm{Mg}_{2} \mathrm{Si}$ in Mg-Si alloys with yttrium. Materials Science and Engineering A, 2005, 392(12): 130-135.

[2] Li C, Wu Y Y, Li H, et al. Morphological evolution and growth mechanism of primary $\mathrm{Mg}_{2} \mathrm{Si}$ phase in Al- $\mathrm{Mg}_{2} \mathrm{Si}$ alloys. Acta Materialia, 2011, 59(3): 1058-1067.

[3] Emamy M, Khorshidi R, and Honarbakhsh R A. The influence of pure $\mathrm{Na}$ on the microstructure and tensile properties of Al- $\mathrm{Mg}_{2} \mathrm{Si}$ metal matrix composite. Materials and Design, 2011, 528: 4337-4342.

[4] Wang $\mathrm{H} Y$, Jiang $Q \mathrm{C}, \mathrm{Ma} B \mathrm{X}$, et al. Modification of $\mathrm{Mg}_{2} \mathrm{Si}$ in MgSi alloys with $\mathrm{K}_{2} \mathrm{TiF}_{6}, \mathrm{KBF}_{4}$ and $\mathrm{KBF}_{4}+\mathrm{K}_{2} \mathrm{TiF}_{6}$. Journal of Alloys and Compounds, 2005, 387(1-2): 105-108.

[5] Wei Xiaolin, Lian Zheng, Zhao Huaizhi, et al. Modification effect of $\mathrm{Yb}$ and $\mathrm{Na}_{3} \mathrm{PO}_{4}$ on microstructure of $\mathrm{Mg}_{2} \mathrm{Si} / \mathrm{Mg}-4 \mathrm{Si}$ alloy and mechanism. China Foundry, 2015, 12(6): 440-445.

[6] Zhao Y G, Qin Q D, Zhao YQ, et al. In situ $\mathrm{Mg}_{2} \mathrm{Si} / \mathrm{Al}-\mathrm{Si}$ composite modified by $\mathrm{K}_{2} \mathrm{TiF}_{6}$. Materials Letters, 2004, 58(16): 2192-2194.

[7] Wang Huiyuan, Wang Wei, Zha Min, et al. Influence of the amount of $\mathrm{KBF}_{4}$ on the morphology of $\mathrm{Mg}_{2} \mathrm{Si}$ in Mg-5Si alloys. Materials Chemistry and Physics, 2008, 108(2-3): 353-358.

[8] Li Chong, Liu Xiangfa, and Zhang Guohua. Heterogeneous nucleating role of $\mathrm{TiB}_{2}$ or $\mathrm{AlP} / \mathrm{TiB}_{2}$ coupled compounds on primary $\mathrm{Mg}_{2} \mathrm{Si}$ in Al-Mg-
Si alloys. Materials Science and Engineering A, 2008, 497(1-2): 432437.

[9] Chen K, Li Z Q, Liu J S, et al. The effect of Ba addition on microstructure of in situ synthesized $\mathrm{Mg}_{2} \mathrm{Si} / \mathrm{Mg}-\mathrm{Zn}-\mathrm{Si}$ composites. Journal of Alloys and Compounds, 2009, 487(1-2): 293-297.

[10] Cong Mengqi, Li Ziquan, Liu Jinsong, et al. Effect of Ca on the microstructure and tensile properties of $\mathrm{Mg}-\mathrm{Zn}-\mathrm{Si}$ alloys at ambient and elevated temperature. Journal of Alloys and Compounds, 2012, 539: 168-173.

[11] Moussa M E, Wal M A, and El-Sheikh A M. Combined effect of highintensity ultrasonic treatment and $\mathrm{Ca}$ addition on modification of primary $\mathrm{Mg}_{2} \mathrm{Si}$ and wear resistance in hypereutectic Mg-Si alloys. Journal of Alloys and Compounds, 2014, 615: 576-581.

[12] Li Chong, Liu Xiangfa, and Wu Yuyin. Refinement and modification performance of Al-P master alloy on primary $\mathrm{Mg}_{2} \mathrm{Si}$ in Al-Mg-Si alloys. Journal of Alloys and Compounds, 2008, 465(1-2): 145-150.

[13] Qin Q D, Zhao Y G, Zhou W, et al. Effect of phosphorus on microstructure and growth manner of primary $\mathrm{Mg}_{2} \mathrm{Si}$ crystal in $\mathrm{Mg}_{2} \mathrm{Si} /$ Al composite. Materials Science and Engineering A, 2007, 447(1-2): 1886-1891.

[14] Ghorbani M R, Emamy M, Khorshidi R, et al. Effect of Mn addition on the microstructure and tensile properties of $\mathrm{Al}-15 \% \mathrm{Mg}_{2} \mathrm{Si}$ composite. Materials Science and Engineering A, 2012, 550: 191-198.

[15] Zhao Y G, Qin Q D, Zhou W, et al. Microstructure of the Ce-modified in situ $\mathrm{Mg}_{2} \mathrm{Si} / \mathrm{Al}-\mathrm{Si}-\mathrm{Cu}$ composite. Journal of Alloys and Compounds, 2005, 389(1-2): L1-L4.

[16] Wu Xiaofeng, Zhang Guangan, Wu Fufa, et al. Influence of neodymium addition on microstructure, tensile properties and fracture behavior of cast Al- $\mathrm{Mg}_{2} \mathrm{Si}$ metal matrix composite. Journal of Rare Earths, 2013, 31(3): 307-312.

[17] Chen Ke and Li Ziquan. Effect of co-modification by $\mathrm{Ba}$ and $\mathrm{Sb}$ on the microstructure of $\mathrm{Mg}_{2} \mathrm{Si} / \mathrm{Mg}-\mathrm{Zn}-\mathrm{Si}$ composite and mechanism. Journal of Alloys and Compounds, 2014, 592: 196-201.

[18] Qin Q D, Zhao Y G, Liu C, et al. Strontium modification and formation of cubic primary $\mathrm{Mg}_{2} \mathrm{Si}$ crystals in $\mathrm{Mg}_{2} \mathrm{Si} / \mathrm{Al}$ composite. Journal of Alloys and Compounds, 2008, 454(1-2): 142-146.

[19] Kim J J, Kim D H, Shin K S, et al. Modification of $\mathrm{Mg}_{2} \mathrm{Si}$ morphology in squeeze cast Mg-Al-Zn-Si alloys by $\mathrm{Ca}$ or $\mathrm{P}$ addition. Modification of Morphology, 1999, 41(3): 333-340.

[20] Schmid E E, Vonoldengurg K, Fromme Yer G. Microstructure and properties of as-cast intermetallic $\mathrm{Mg}_{2} \mathrm{Si}$-Al alloys. Zeitschrift Fur Metallkunde, 1990, 81(11): 809-815.

[21] Pan Yichuan, Liu Xiangfa. Heterogeneous nucleation of $\mathrm{a}-\mathrm{Mg}, \mathrm{Mg}_{2} \mathrm{Si}$ in Mg alloys and development of relevant master alloys. Shandong University, October 20, 2006.

[22] Hou Jing, Li Chong, Liu Xiangfa. Nucleating role of an effective in situ $\mathrm{Mg}_{3} \mathrm{P}_{2}$ on $\mathrm{Mg}_{2} \mathrm{Si}$ in Mg-Al-Si alloys. Journal of Alloys and Compounds, 2011, 509: 735-739.

[23] Pan Yichuan, Liu Xiangfa, and Yang Hua. Microstructural formation in a hypereutectic Mg-Si alloy. Materials Characterization, 2005, 55(3): 241-247.

[24] Yan Hong, Hu Yong, and Wu Xiaoqian. Influence of Sb modification on microstructures and mechanical properties of $\mathrm{Mg}_{2} \mathrm{Si} / \mathrm{AM} 60$ composites. Trans Nonferrous Met Soc China, 2010, 20: S411-S415.

[25] Nasiri N, Emamy M, and Malekan A. Microstructural evolution and tensile properties of the in situ $\mathrm{Al}-15 \% \mathrm{Mg}_{2} \mathrm{Si}$ composite with extra $\mathrm{Si}$ contents. Materials and Design, 2012, 37: 215-222.

[26] Peng Lei, Chen Gang, Zhao Yutao, et al. Influence of solution treatment on microstructure and properties of in-situ $\mathrm{Mg}_{2} \mathrm{Si} / \mathrm{AZ}$ 21D composites. Trans Nonferrous Met Soc China, 2011, 21(11): 2365-2371.

[27] Hadian R, Emamy M, Varahram N, et al. The effect of Li on the tensile properties of cast Al- $\mathrm{Mg}_{2} \mathrm{Si}$ metal matrix composite. Materials Science and Engineering A, 2008, 490: 250-257. 